\title{
Severe soft tissue necrosis after extravasation of mitoxantrone: Case report
}

\author{
Mamood Kara MD FRCSC, Douglas C Ross MD FRCSC \\ Hand and Upper Limb Centre and Division of Plastic Surgery, St Joseph's Health Centre, \\ London, Ontario
}

\begin{abstract}
M Kara, DC Ross. Severe soft tissue necrosis after extravasation of mitoxantrone: Case report. Can J Plast Surg 1998;6(4):204-206. Subcutaneous extravasation of chemotherapeutic agents is a relatively common occurrence that is usually treated with non-operative techniques. An exception is injuries caused by doxorubicin (adriamycin), which can lead to progressive necrosis. We report a similar pattern of progression after extravasation of a newer agent - mitoxantrone. Wide excision and flap closure were required for wound healing. Mitoxantrone extravasation injuries require close monitoring and may produce full thickness necrosis followed by enlarging ulceration.
\end{abstract}

Key Words: Chemotherapy, Extravasation, Necrosis

\section{Grave nécrose des tissus mous après extravasation de mitoxantrone : rapport de cas}

RÉSUMÉ : L'extravasation sous-cutanée d'agents chimiothérapeutiques survient relativement souvent et on la traite habituellement par technique non opératoire. Une exception est la lésion causée par la doxorubicine (adriamycine), qui peut entraîner une nécrose progressive. Nous signalons ici une situation similaire après extravasation d'un agent plus récent, le mitoxantrone. Il a fallu procéder à une excision large et à une fermeture avec lambeau pour faire guérir la plaie. Les lésions consécutives à l'extravasation de mitoxantrone requièrent une surveillance attentive et peuvent engendrer une nécrose de pleine épaisseur suivie d'une ulcération croissante.

$\mathbf{I}_{\mathrm{u}}^{\mathrm{n}}$ ntravenous infusion of biologically active substances is ubiquitous in modern medical practice. As such, extravasation or leakage into surrounding tissues is a common occurrence. In most cases, the extravasation results in a minor reaction with localized pain and swelling, which eventually subside. Extravasation of chemotherapeutic agents has a variable reported incidence, ranging from $0.01 \%$ to $6 \%(1,2)$. Rarely, such extravasations result in soft tissue necrosis and skin ulceration. This occurs in approximately $11 \%$ of patients who suffer an extravasation injury (3). Doxorubicin (anthracycline derivatives), mechlorethamine (nitrogen mustard), mitomycin and the vinca alkaloids (vinblastine, vincristine)

Correspondence and reprints: Dr Douglas C Ross, Hand \& Upper Limb Centre \& Division of Plastic Surgery, St Joseph's Health Centre, London, Ontario, N6A 4L6. Telephone 519-646-6048, fax 519-646-6049, e-maildross@julian.uwo.ca are cytotoxic drugs that are likely to cause ulceration after extravasation (2).

Mitoxantrone is a recently released antineoplastic drug. Animal tests for vesicant activity (4) and initial clinical trials have revealed no adverse effects or vesicant activity on extravasation $(5,6)$. However, we have recently encountered a case of progressive skin ulceration and soft tissue necrosis from mitoxantrone extravasation.

\section{CASE PRESENTATION}

A 73-year-old man developed non-Hodgkin's lymphoma. He was started on a course of chemotherapy consisting of cyclophosphamide $1350 \mathrm{mg}$ intravenously, mitoxantrone $18 \mathrm{mg}$ intravenously, vincristine $2 \mathrm{mg}$ intravenously and prednisone $100 \mathrm{mg}$ orally on a daily basis for five days per course. During the third course, while infusing mitoxantrone, the intravenous line became interstitial and an extravasation 


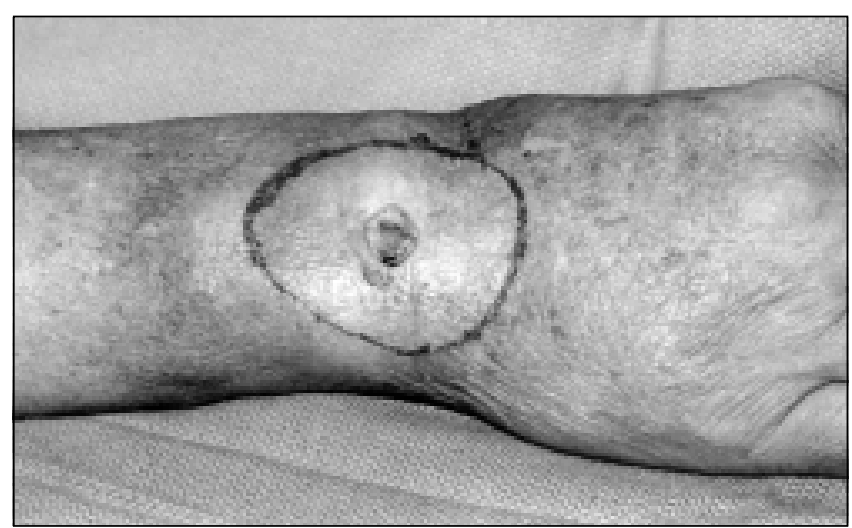

Figure 1) Ulcer with extent of undermining outlined by marking

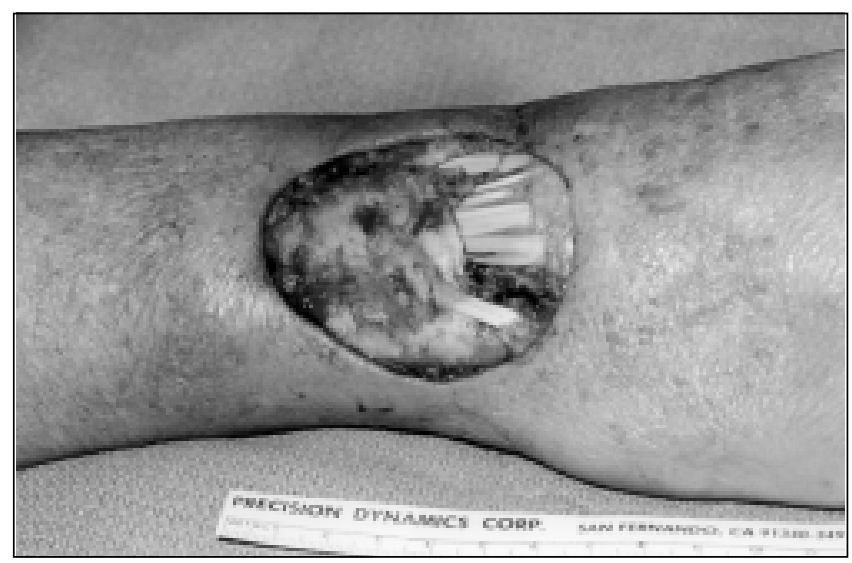

Figure 2) Defect remaining after debridement

of the agent occurred on the dorsum of the right wrist. He experienced immediate pain and swelling.

The intravenous line was removed and the hand was treated with splinting, elevation and application of ice packs. The area remained painful and swollen for approximately three weeks, when the overlying skin began to ulcerate. He presented to the plastic surgery clinic with a $1 \mathrm{~cm}$ diameter superficial ulcer surrounded by a zone of erythema and induration measuring $6 \mathrm{~cm}$ in diameter.

He was started on dressing changes with the hope of secondary intention healing but at two weeks' follow-up there was progression of the ulceration with no evidence of granulation tissue nor epithelialization (Figure 1).

At operation, a flask-shaped area of necrosis with wide undermining extended through the extensor retinaculum and postdebridement extensor tendons remained without epitenon (Figure 2). The defect measured $6 \times 6 \mathrm{~cm}$. A reverse radial forearm flap was used for closure but $24 \mathrm{~h}$ postoperatively he developed a hematoma deep to the flap with pedicle compression. The flap went on to full thickness necrosis and the defect was reconstructed with an ipsilateral free lateral arm flap (Figure 3). All wounds subsequently healed and he went on to complete his next chemotherapy course three weeks later. He regained full flexion and extension of the wrist, fingers and thumb.

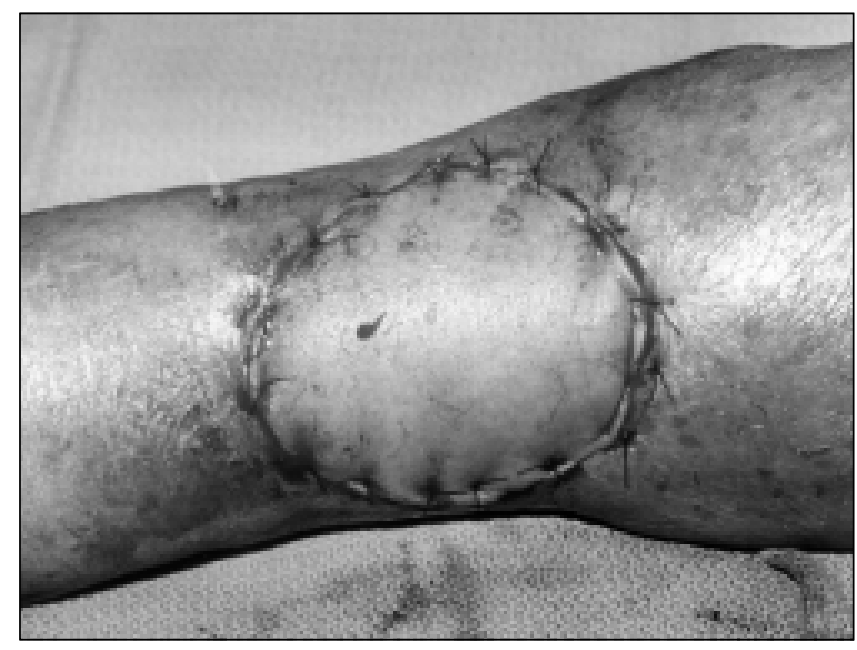

Figure 3) Immediate postoperative appearance after wound closure with lateral arm flap

\section{DISCUSSION}

A useful classification for extravasation injuries has been proposed by Rudolph and Larson (7). The types of extravasated substances can be divided into those that bind tissue nucleic acids and those that do not. The former group has longer term effects that may persist for many months. The latter group has a brief effect with variable severity. Doxorubicin is an anthracycline derivative that binds tissue nucleic acids upon extravasation. Mitoxantrone, which is also an anthracycline derivative, would be expected to have similar effects.

The pathogenesis of doxorubicin-induced extravasation injury is well understood and serves as a model. Histological studies in animal models reveal a lack of inflammatory response, with a deficiency in wound contraction and other phases of wound healing (8). These actions are thought to be due to binding of doxorubicin with intracellular DNA (9). In this form, doxorubicin is known to remain in the tissue and have a destructive effect for as long as five months (10). Doxorubicin-DNA complexes are released from necrotic cells and taken up by surrounding viable cells. The cycle of progressive necrosis and ulceration is perpetuated $(11,12)$.

In summary, mitoxantrone extravasation may be responsible for severe soft tissue necrosis. It appears to behave like doxorubicin. The initial effects appear a few days after the extravasation and may progress for several weeks to months. An enlarging lesion should be considered for excision to prevent further tissue destruction.

\section{REFERENCES}

1. Cox K, Stuart-Harris R, Abdini G, Grygiel J, Raghavan D. The management of cytotoxic-drug extravasation: guide-lines drawn up by a working party for the Clinical Oncological Society of Australia. Med J Aust 1988;148:185-9.

2. Ignoffo R, Freidman MA. Therapy of local toxicities caused by extravasation of cancer chemotherapeutic drugs. Cancer Treat Rev 1980;7:17-21. 
3. Larson DL. What is the appropriate management of tissue extravasation by antitumor agents? Plast Reconstr Surg 1985;75:397-405.

4. Dorr RT, Alberts DS, Soble M. Lack of experimental vesicant activity for the anticancer agents cisplatin, melphalan, and mitoxantrone. Cancer Chemother Pharmacol 1986;16:91-4.

5. Von Hoff DD, Pollard E, Kuhn J, Murray E, Coltman CA Jr. Phase I clinical investigation of 1,4-dihydroxy-5,8-bis ((2-((2-hydroxyethyl) amino)ethyl)-amino)-9,10 anthracenedione dihydrochloride (NSC 301739), a new anthracenedione. Cancer Res 1980;40:1516-8.

6. Wynert WR, Harvey HA, Lipton A, Scweitzer J, White DS. Phase I study of a 5-day schedule of mitoxantrone (dihydroxyanthracenedione). Cancer Treat Rep 1982;66:1303-6.

7. Rudolph R, Larson DL. Etiology and treatment of chemotherapeutic agent extravasation injuries: a review. J Clin Oncol 1987;5:1116-26.

8. Luedke D, Kennedy P, Rietschel R. Histopathogenesis of skin and subcutaneous injury induced by adriamycin (doxorubicin). Plast Reconstr Surg 1985;63:463-8.

9. Rudolph R, Woodward M, Hurn L. Ultrastructure of doxorubicin (adriamycin)-induced skin ulcers in rats. Cancer Res 1979;39:3689-93.

10. Garnick M, Israel M, Khetarpal V, et al. Persistence of anthracycline levels following dermal and subcutaneous adriamycin extravasation. Proc Am Assoc Cancer Res 1981;96-101.

11. Silvestrini R, Gambarucci D, Desidia T. Attivita biologica dell adriamicina in vitro. Tumori 1970;56:137-41.

12. Zweig JI, Kabakow B, Wallach RC, Valencic M, Zalusky R. Rational effective treatment of skin ulcers due to adriamycin. Cancer Treat Rep 1979;63:2101-3. 